\title{
New data concerning “large blades” in Catalonia: Apt- Forcalquier chert in the Penedès (south of Barcelona) during the Late Neolithic - Chalcolithic
}

\author{
Javier Mangado $^{1}$, Jean Vaquer ${ }^{2}$, Juan Francisco Gibaja ${ }^{3}$, F. Xavier Oms ${ }^{1}$, \\ Artur Cebrià ${ }^{1}$, Cynthia B. González ${ }^{1}$, Araceli Martín ${ }^{4}$, Dioscórides Marín ${ }^{5}$
}

1. SERP-UB (Seminari d'Estudis i Recerques Prehistòriques - Universitat de Barcelona), Facultat de Geografia i

Història. c/Montalegre 6. 08001 Barcelona, Spain. Email: Mangado: mangado@ub.edu;

Oms: xavieroms@gmail.com; Cebrià: arturcebria@gmail.com; González: cynthiab.gonzalezo@gmail.com

2. TRACES - UMR 5608 (Travaux et Recherches Archéologiques sur les Cultures, les Espaces et les Sociétés). Maison de la Recherche 5, allée Antonio Machado 31058 Toulouse Cedex 9, France.

Email: jean-sebastien.vaquer@orange.fr

3. IMF-CSIC (Institución Milá y Fontanals - Consejo Superior de Investigaciones Científicas). c/Egipcíaques, 15. 08001. Barcelona, Spain. Email: jfgibaja@imf.csic.es

4. Servei d’Arqueologia. c/Portaferrisa 1. 08001. Barcelona, Spain. Email: amcolliga@yahoo.es

5. Departament de Història, Universitat de Lleida, Plaza Victor Siurana, 1, 25003 Lleida, Spain.

Email: diosco.marin@gmail.com

\begin{abstract}
:
The study of large chert blades documented in funerary contexts from the Late Neolithic to the Early Bronze Age in the north-eastern part of Iberia has been addressed in recent works by the authors, in which 49 burial sites have been registered with more than 200 large chert blades. In this paper the recent data obtained from the study of seven archaeological sites located in the region of the Penedès (southwest of Barcelona) is presented.

The macroscopic characterization of the knapped stone industries shows their great variety regarding the origin of the siliceous raw material, often coming from outside the analysed region. In some cases their macroscopic features link them to Apt-Forcalquier chert (Haut Provence, France), which was widely distributed in the form of large blades during these phases of Late Catalan prehistory.

The absence of evidence of the chaîne opératoire production of this type of foreign chert in the lithic assemblages in Catalonia lead to the supposition that the dispersion of the blades was done as trade items, and only in a few cases were highly complex technological tools of this kind of raw material distributed (e.g., daggers). Use-wear analysis reveals that these blades were not merely luxury items in grave goods. Far from this idea, they have to be considered as functional, even multifunctional, items. All the same, it is thought that they must have had an important value because they moved from the domestic sphere to the graves. In fact, the pieces that usually remain are not small fragments, but whole or almost whole, large blades that normally remain effective.
\end{abstract}

Keywords: "large blades"; Apt-Forcalquier chert; ancient trade; lithic technology; grave goods; Neolithic-Chalcolithic; North-eastern Iberia

Published by the School of History, Classics and Archaeology, University of Edinburgh ISSN: 2055-0472. URL: http://journals.ed.ac.uk/lithicstudies/

This work is licensed under a Creative Commons Attribution 2.5 UK: Scotland License. 


\section{Introduction}

The Middle to Late Neolithic transition in the north-east of Iberia is characterized by mortuary behaviour and cultural changes determined by occupational areas and "luxury" items in grave goods (Daura et al. 2015). The study of large chert blades documented in funerary contexts from the Late Neolithic to the Early Bronze Age in the north-eastern part of Iberia has been addressed in recent works (Gibaja et al. 2004; Gibaja et al. 2009; Terradas et al. 2005; Terradas et al. 2012) in which 49 burial sites have been registered (22 burial caves or rock shelters and 27 megalithic tombs) with more than two hundred large chert blades. The aim of this paper is to present the recent data obtained from the study of seven archaeological sites, defined as burial caves, belonging to the Late Neolithic and Chalcolithic, all them, except Cova de l'Avi Figure 1: 7), located in the historical region of the Penedès (southwest of Barcelona), in which many "large blades" have been studied.

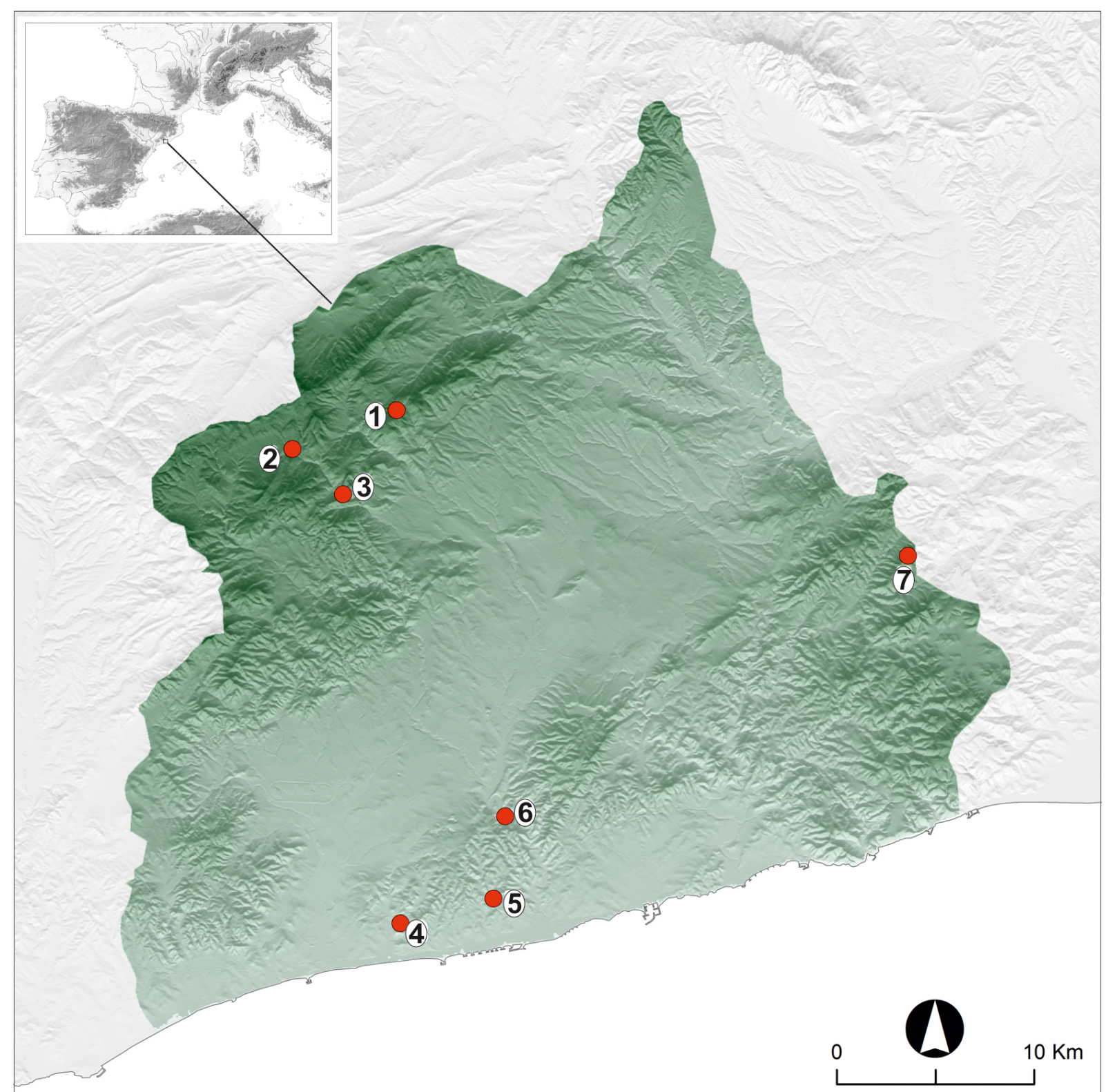

Figure 1. Map of the study area and site locations. 1. Cova de la Guineu; 2. Cova de la Font del Molinot; 3. Esquerda de les Roques del Pany; 4. Cova Foradada; 5. Avenc de Sant Antoni; 6. Cova del Pantà de Foix; 7. Cova de l'Avi. 
The area of this study, the Penedès, is a natural region located between the Catalan Precoastal mountain range and the Mediterranean Sea. The region has its own geographical characteristics that allow us to distinguish four units: The Catalan Pre-coastal mountain range, the Catalan Pre-coastal depression, the Catalan Litoral mountain range and the coastal plain. The archaeological materials analysed in this paper comes from seven burial caves located in both mountain ranges. Cova de la Guineu (734 m ASL), Cova de la Font del Molinot (600 m ASL) and Esquerda de les Roques del Pany (485 m ASL) are located in the high mountains area (Pre-coastal mountains), while Cova Foradada (100 m ASL), Cova del Pantà de Foix $(\approx 100 \mathrm{~m} \mathrm{ASL})$ and Avenc de Sant Antoni (113 m ASL) are located near the coastal plain. Finally, out of both sets, Cova de l'Avi in the north-eastern part of the Garraf Mountains is located at $523 \mathrm{~m} \mathrm{ASL}$, and represents chronologically the earliest site where these cultural changes and mortuary practices have been documented in the north-east of Iberia (Daura et al. 2015).

\subsection{Sites, lithic materials and available radiocarbon dates}

Cova de la Guineu was discovered in 1983 and the site has been excavated since 1988 by the SERP research group. The stratigraphic sequence of the site encompasses 12 archaeological levels. The burial use of the cave (level Ic) correspond to a paradolmenic collective burial space (around $29 \mathrm{~m}^{2}$ ) with about fifty individuals and a lithic assemblage including 27 large blades or fragments and 6 bifacial points (Figure 2). Three radiocarbon dates were obtained from this level (Table 1) (Oms et al. 2016).

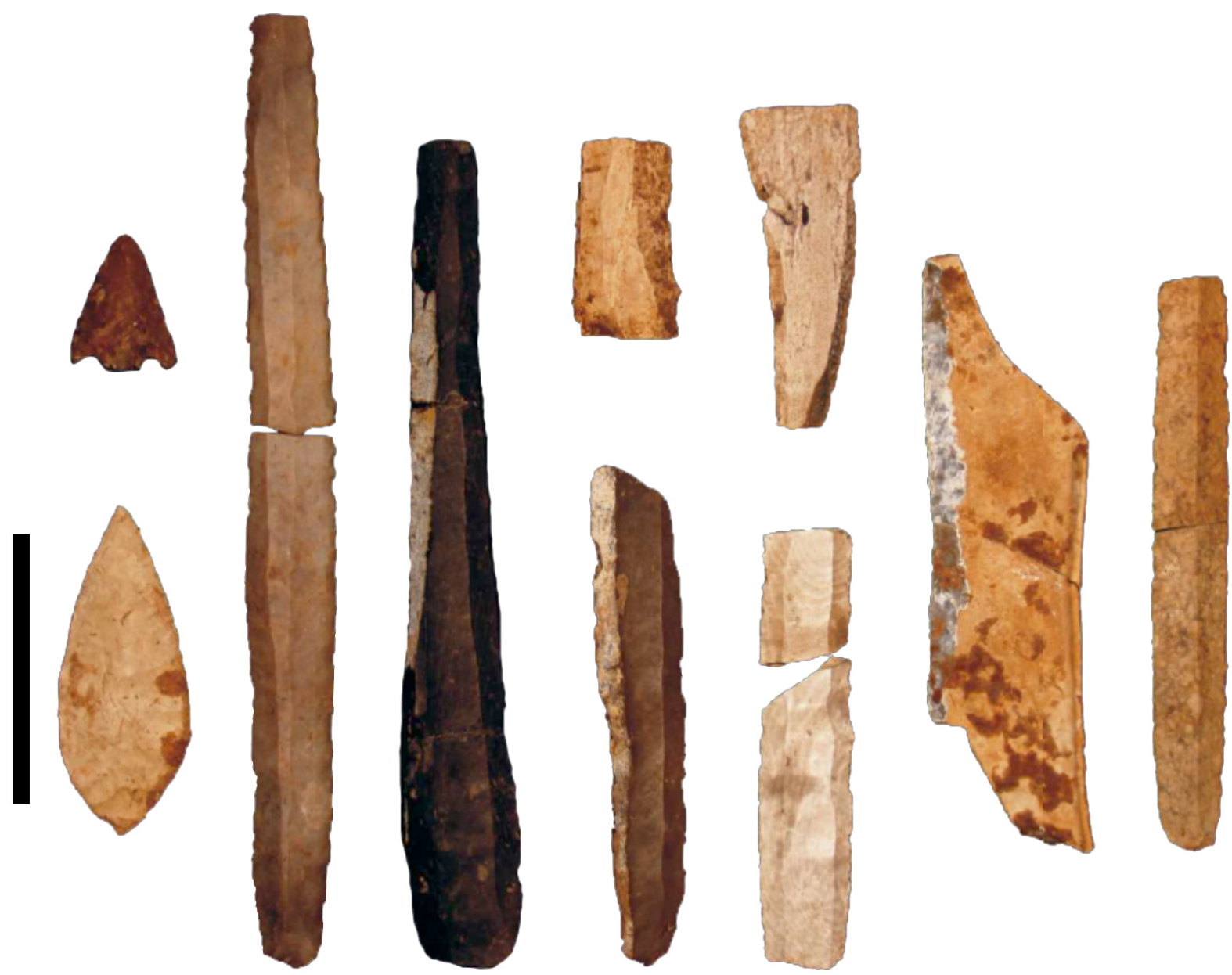

Figure 2. Part of the lithic set analysed from Cova de la Guineu. Scale bar $=3 \mathrm{~cm}$. 
Table 1. NMI, lithic set and radiocarbon dates from analysed sites.

\begin{tabular}{|c|c|c|c|c|c|c|c|c|}
\hline Site & Layer & NMI & $\begin{array}{l}\text { Area } \\
\left(\mathrm{m}^{2}\right)\end{array}$ & $\begin{array}{c}\text { Lithic } \\
\text { pieces }\end{array}$ & Sample & Lab. code & BP date & Cal BC $2 \sigma$ \\
\hline \multirow[t]{2}{*}{ Cova de l'Avi } & \multirow[t]{2}{*}{-} & \multirow[t]{2}{*}{12} & \multirow[t]{2}{*}{12} & \multirow[t]{2}{*}{10} & H. bone & OxA-29610 & $4703 \pm 32 B P$ & $3631-3372$ \\
\hline & & & & & $\mathrm{H}$. bone & OxA-29611 & $4696 \pm 30 B P$ & $3629-3372$ \\
\hline \multicolumn{2}{|l|}{$\begin{array}{l}\text { Cova de la Font del } \\
\text { Molinot }\end{array}$} & 10 & 35 & 20 & Charcoal & MC-1112 & $4650 \pm 60 \mathrm{BP}$ & $3519-3379$ \\
\hline Cova del Pantà de & - & 38 & 14 & 7 & H. bone & OxA-25037 & $4530 \pm 36$ BP & $3420-3060$ \\
\hline \multirow[t]{3}{*}{ Foix } & & & & & H. bone & OxA-25038 & $4499 \pm 37$ BР & $3400-3040$ \\
\hline & & & & & H. bone & OxA-25036 & $4422 \pm 35 \mathrm{BP}$ & $3340-2860$ \\
\hline & & & & & H. bone & OxA-25039 & $4204 \pm 38$ BP & $2960-2640$ \\
\hline \multirow[t]{3}{*}{ Cova de la Guineu } & Ic & c. 50 & 29 & 33 & Charcoal & OxA-23641 & $4156 \pm 28$ BP & $2920-2600$ \\
\hline & & & & & H. bone & OxA-16966 & $4385 \pm 32 \mathrm{BP}$ & $3120-2880$ \\
\hline & & & & & H. bone & OxA-16881 & $4110 \pm 38$ BР & $2940-2500$ \\
\hline \multirow[t]{2}{*}{ Cova Foradada } & $\mathrm{Ib}$ & c.30 & 19 & 9 & H. bone & OxA-23529 & $4375 \pm 31 \mathrm{BP}$ & $3090-2890$ \\
\hline & & & & & H. bone & OxA-23639 & $4016 \pm 29$ ВР & $2610-2450$ \\
\hline $\begin{array}{l}\text { Esquerda de les } \\
\text { Roques del Pany }\end{array}$ & - & - & c. 50 & 16 & \multicolumn{4}{|c|}{ Old research (not yet dated) } \\
\hline $\begin{array}{l}\text { Avenc de Sant } \\
\text { Antoni }\end{array}$ & - & - & c. 100 & 3 & \multicolumn{4}{|c|}{ Old research (not yet dated) } \\
\hline
\end{tabular}

Cova Foradada was discovered in 1997, and has been under excavation by SERP since 1999. The site is located $1 \mathrm{~km}$ away from the sea. The stratigraphic sequence preserves 5 levels, with level $\mathrm{Ib}$ (around $19 \mathrm{~m}^{2}$ ) corresponding to the burial use of the cave, in which several human skeletal remains (c.30 individuals) and lithics (2 fragments of large blade and 7 bifacial points) (Figure 3) were documented in association with many necklace beads (Cebrià et al. 2013). Two radiocarbon dates were obtained from human bones (Table 1 and Figure 4).

The Cova del Pantà de Foix site, discovered during the construction of a reservoir in 1923 on the Foix River is currently underwater. The archaeological area had and irregular shape, $6.40 \mathrm{~m}$ long and $3.50 \mathrm{~m}$ wide, with approximately 14 square meters for the burial level. The excavation at that time yielded human remains of 38 different individuals and a set of lithics with 6 large blades or blade fragments and 1 bifacial point (Figure 5).

The recent publication of the microscopic use-wear analyses of the six blades and blades fragments, show in each case the same type of deformations caused by its use for harvesting cereals. All of the blades also show resharpening. The arrowhead has an impact fracture, probably related with its use as a projectile. Recent radiocarbon dates obtained from several human bones have been published (Cebrià et al. 2013) (Table 1 and Figure 4).

Cova de la Font del Molinot has an area of $20 \mathrm{~m}^{2}$. Discovered in 1936, the site was excavated in 1974. During the fieldwork, ten individuals were recovered, and 6 arrowheads and 13 large blades or blade fragments have been identified (Table 1, Figure 6 and Figure 4). At this site, a chert dagger blade with parallel, 'ripple-flake' retouch covering its entire surface, made from a polished roughout was also discovered.

The burial level intensively affected by poaching archaeological activities had approximately $12 \mathrm{~m}^{2}$ and 12 individuals. A chert dagger blade with parallel, 'ripple-flake' retouch covering its entire surface, made also from a polished roughout, is the most outstanding piece from this site (Figure 8). This site shows the oldest Carbon-14 dates for this region (Table 1 and Figure 4).

La Cova de l'Avi, although it is located at the edge of the study area, presents 4 large blades and 5 arrowheads (Figure 7). 

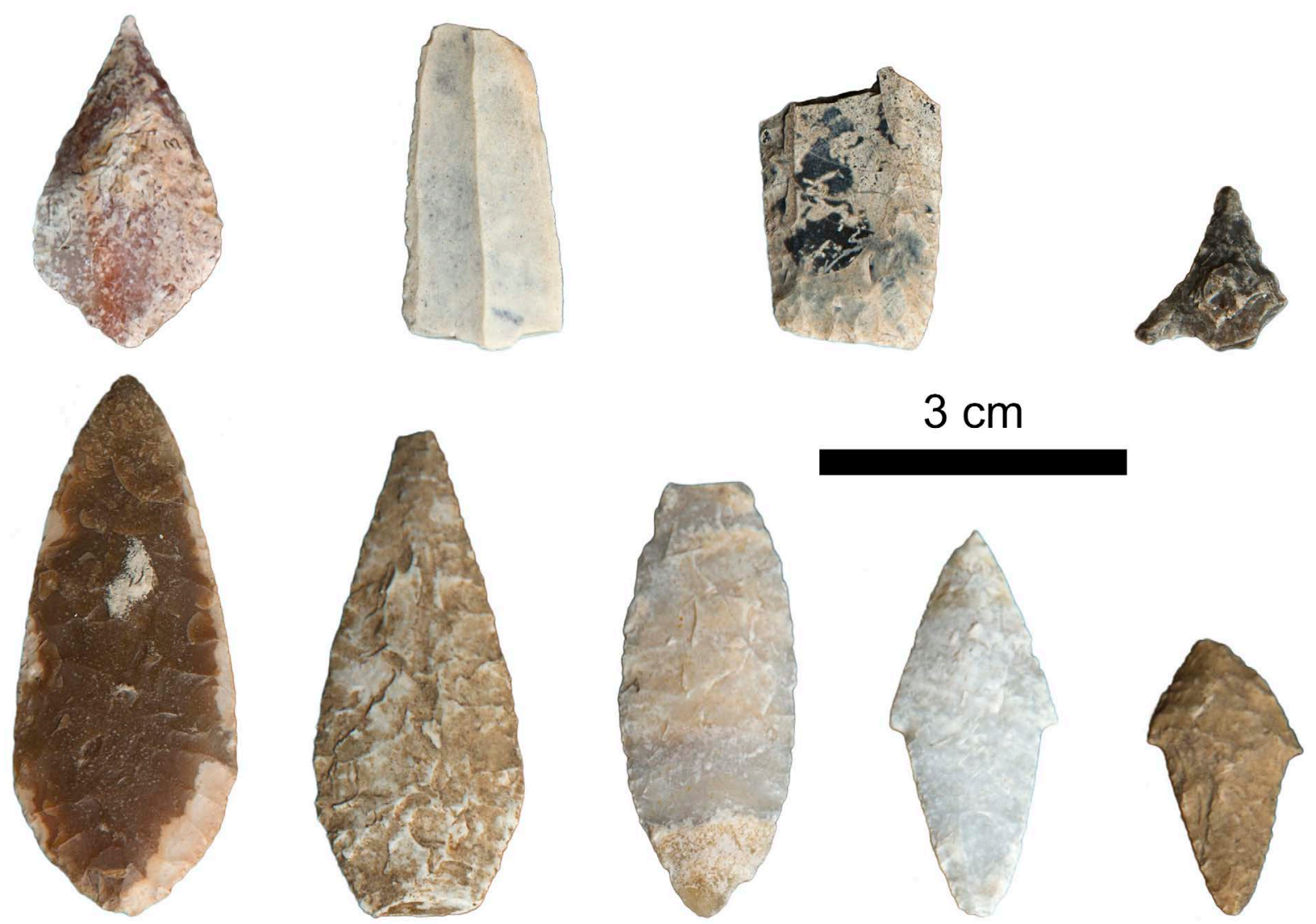

Figure 3. Lithic assemblage from Cova Foradada

Cova de l'Avi OxA-29610

Cova de I'Avi OxA-29611

Cova de la Font del Molinot MC-1112

Cova del Pantà de Foix OxA-25037

Cova del Pantà de Foix OxA-25038

Cova del Pantà de Foix OxA-25036

Cova del Pantà de Foix OxA-25039

Cova de la Guineu OxA-23641

Cova de la Guineu OxA-16966

Cova de la Guineu OxA-16881

Cova Foradada OxA-23529

Cova Foradada OxA-23639

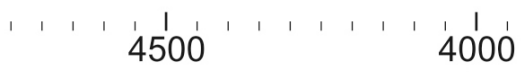
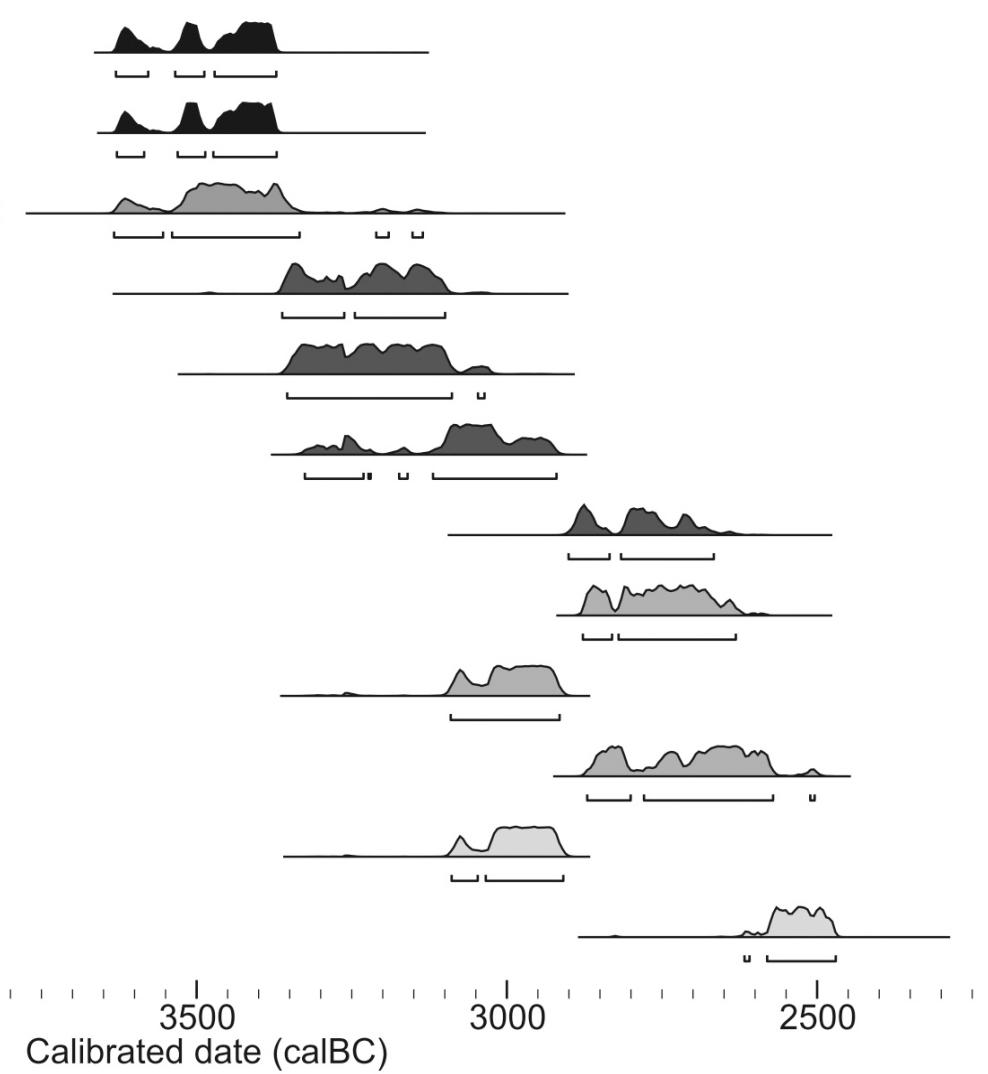

Figure 4. Calibrated results of all ${ }^{14} \mathrm{C}$ dates available from analysed sites in the Penedès region. Calibration with the OxCal4.2 software and the IntCal13 dataset, results shown with 2 sigma probability (Bronk Ramsey, 2013; Reimer et al. 2013). 

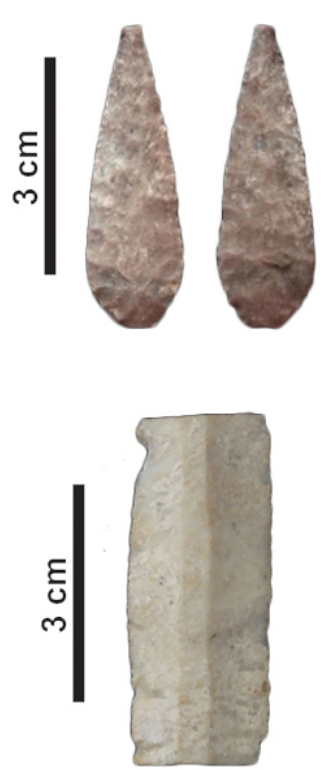
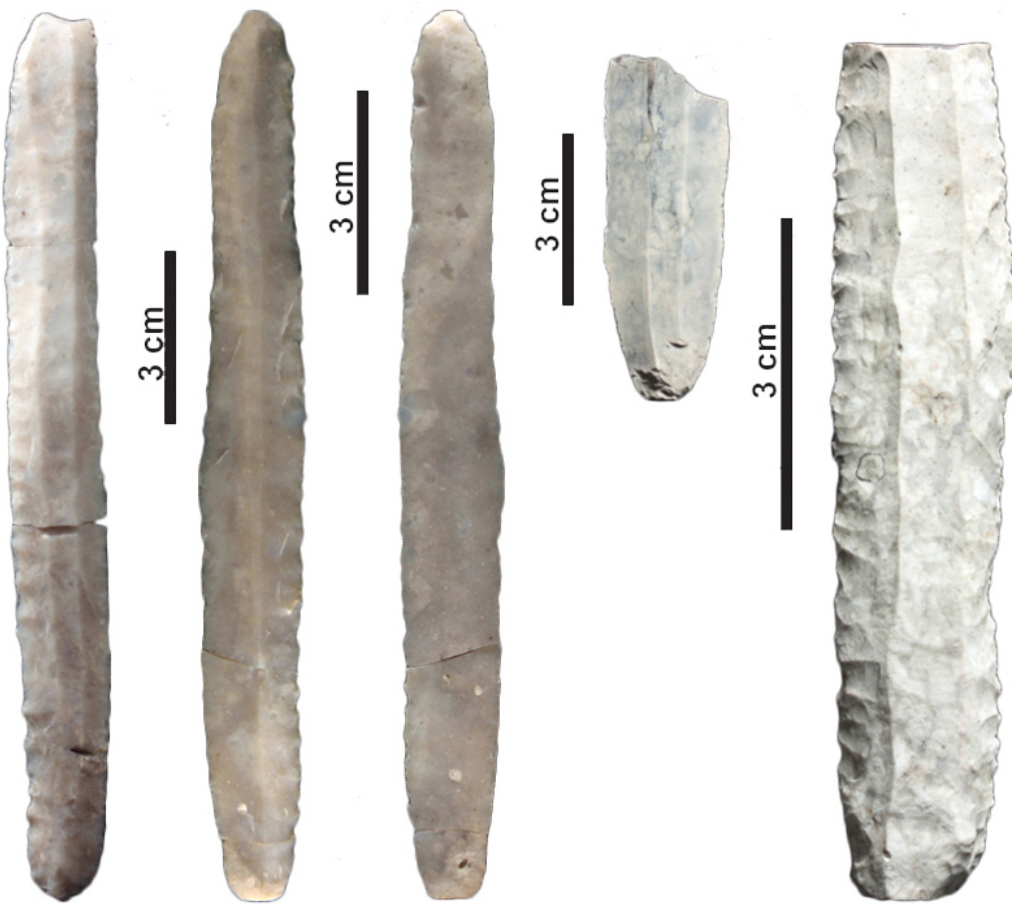

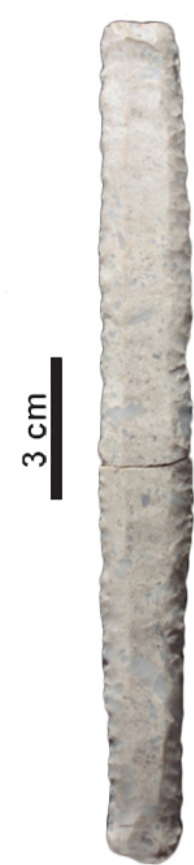

Figure 5. The lithics analysed from Cova del Pantà de Foix
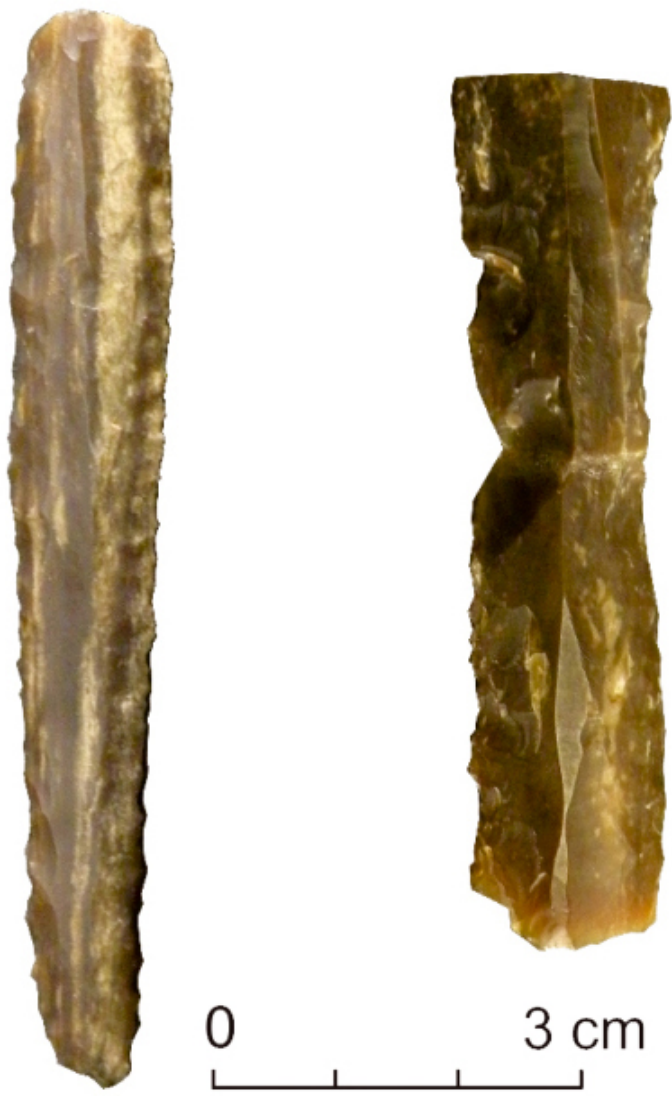

Figure 6. Two Fortcalquier large blades from Cova de la Font del Molinot 

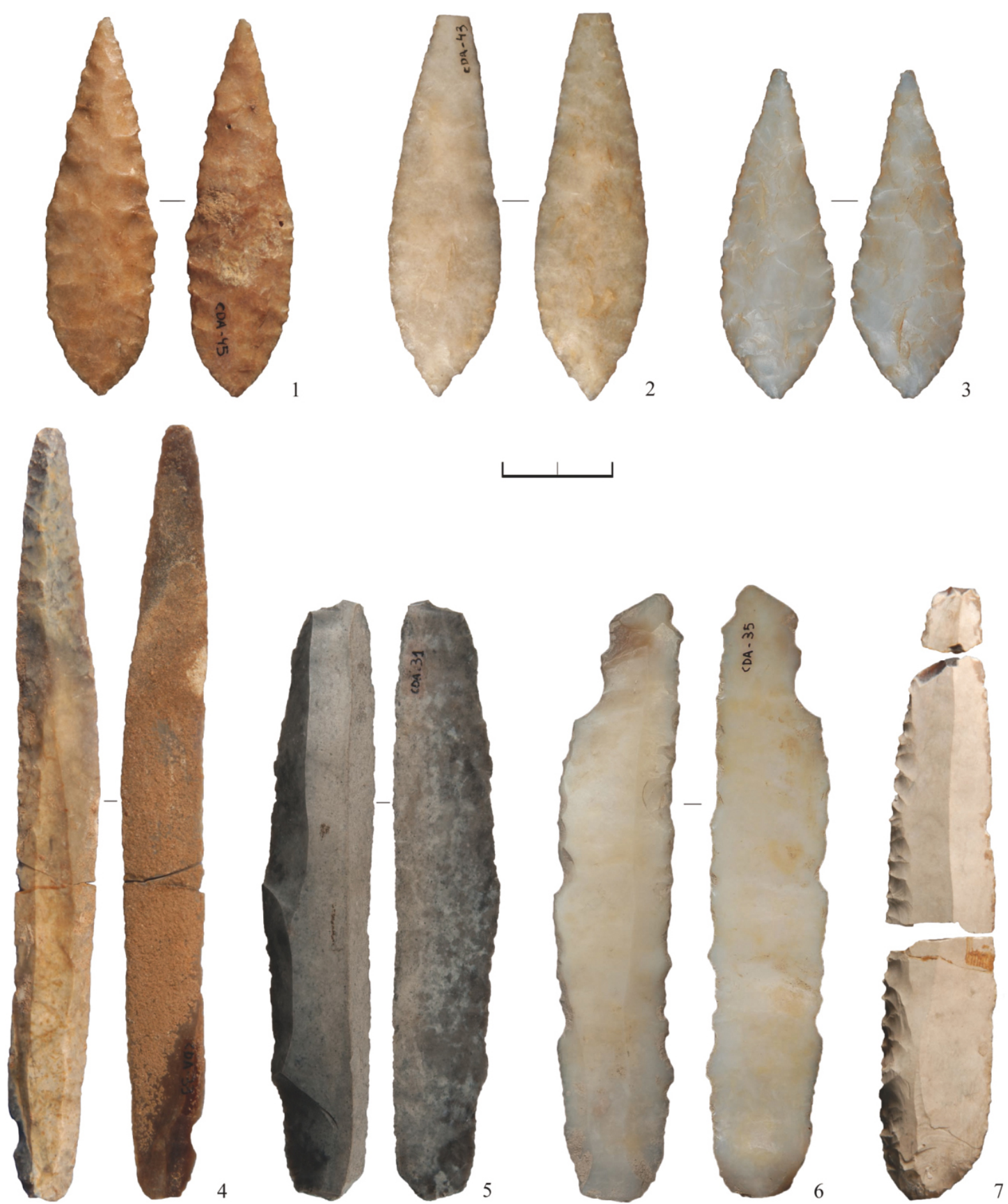

Figure 7. Part of the lithic set analysed from Cova de l'Avi. Scale bar $=2 \mathrm{~cm}$ (in $1 \mathrm{~cm}$ segments).

The old archaeological work during 1928 at the site of Esquerda de les Roques del Pany, yielded a collection of 12 large blades or blade fragments and 4 arrowheads together with several human bones in an area about $50 \mathrm{~m}^{2}$. No radiocarbon dates are available yet for this site (Table 1).

The last site that was analysed for this paper is Avenc de Sant Antoni, discovered in 1927. The site was almost fully excavated during the 1960s, recovering several potsherds and 2 large blade fragments. Recently, another fragment of large blade made from Forcalquier chert type has been recovered. This site is not radiocarbon dated either (Table 1). 


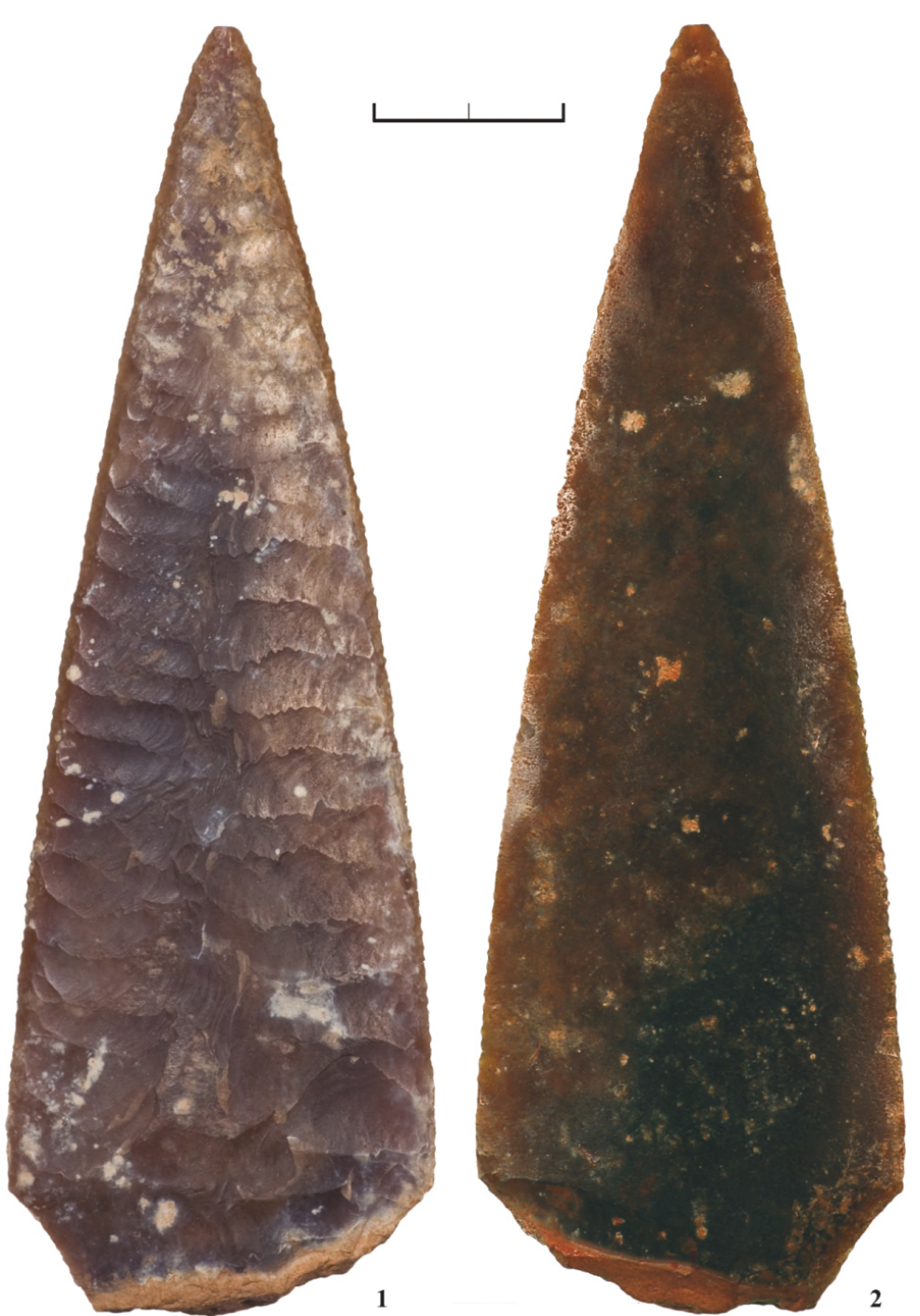

Figure 8. Forcalquier chert dagger, Chataigners type, recovered in Cova de l'Avi. (Photo by J. Vaquer.) Scale bars $=2 \mathrm{~cm}$ (in $1 \mathrm{~cm}$ segments).

\section{Methods}

\subsection{Macroscopic Archaeopetrological approach}

We have to note that all of the analysed items are considered grave goods and also that a large part of them are catalogued and preserved in different museums. For those reasons, from the beginning of this project the possible use of any destructive description method, such as petrographic thin sections, was completely discluded.

The collection analysed for this paper was a set of large blades and blade fragments (67); arrowheads (29), daggers (2); a total number of 98 different pieces. The archaeopetrological method used was macroscopic characterisation. The description of macroscopic parameters was carried out with a binocular lens Olympus microscope, model SZ61, with a range of magnification between 0.67x and 4.5x. A KL1500 LCD cold light lamp and a complementary TH4-200 transmitted light lamp was also used. The images were taken with an Olympus SC30 camera integrated with the binocular microscope, using the software analySIS getIT.

For each analysed item, we took into account several parameters related with their macroscopical aspect: texture, structure, main components and their abundance, micropaleontology, patinas, and other changes observed, in order to approach the original 
depositional sedimentary environment that had been previously defined as: marine, continental: lacustrine, brecciated or evaporitic, burned items and undetermined items.

\subsection{Technological and typological approaches}

Concerning the technological approach undertaken in this paper it should be noted that, on one hand, part of the analysed collections was assembled during old fieldwork, and for this reason, the original collection integrity remains uncertain, and at that time, the excavation methodology was also not carefully developed, and some large blades were fractured into several fragments.

On the other hand, usually, lithics recovered from burials correspond only with finished tools, a fact that hinders definition of the C.O.L (Chaîne Opératoire Lithique), in absence of the main part of the débitage products. In this study the first approach to the C.O.L of large blades was carried out taking into consideration their thickness, regularity of the ridges, profile, sizes, butt types and other parameters that suggest that an important variability of knapping techniques was employed, ranging from direct hard percussion to foot pressure knapping (Table 2).

Table 2. Technological approach to large blades. Butt types. The asterisk (*) corresponds to Apt-Forcalquier blanks. Sites. 1. Cova de la Guineu; 2. Cova de la Font del Molinot; 3. Esquerda de les Roques del Pany; 4. Cova Foradada; 5. Avenc de Sant Antoni: 6. Cova del Pantà de Foix; 7. Cova de l'Avi.

\begin{tabular}{|c|c|c|c|c|c|c|c|c|}
\hline \multirow[b]{2}{*}{ Large blades } & \multirow[b]{2}{*}{ Butt type } & \multicolumn{7}{|c|}{ Sites } \\
\hline & & 1 & 2 & 3 & 4 & 5 & 6 & 7 \\
\hline \multirow[t]{5}{*}{ Complete } & Flat butt & & + & + & & & + & $*_{+}$ \\
\hline & Dihedral butt & & & & & & + & + \\
\hline & Facetted butt & & + & & & & & + \\
\hline & Undetermined butt & $*_{+}$ & & + & & & & \\
\hline & Missing & +++ & & $*$ & & & & \\
\hline \multirow[t]{6}{*}{ Proximal fragment } & Flat butt & +++ & ++ & + & & & $*+$ & \\
\hline & Dihedral butt & + & & + & & & + & \\
\hline & Facetted butt & & ++ & & & & & \\
\hline & Punctiform butt & & & + & & & & \\
\hline & Undetermined butt & ++ & $*_{+}$ & & & & & \\
\hline & Missing & + & + & + & & & & \\
\hline Mesial fragment & & $* * *+++++$ & ++ & $*_{+}$ & + & ++ & + & \\
\hline Distal fragment & & $*++++++$ & ++ & $*++$ & + & $*$ & & \\
\hline Total & & 27 & 13 & 12 & 2 & 3 & 6 & 4 \\
\hline
\end{tabular}

The typological definition of projectile points was based on the previous works of $\mathrm{J}$. Juan-Cabanilles (2008) (Table 3). Two different main types of projectile points have to be pointed out. First, diamond-shaped projectile points usually complete or with little impact fractures; and second, winged and stemmed points. Neither type usually has a defined butt, related with its retouch technology. 
Table 3. Technological approach to arrowheads. Types of butt. Sites. 1. Cova de la Guineu; 2. Cova de la Font del Molinot; 3. Esquerda de les Roques del Pany; 4. Cova Foradada; 5. Avenc de Sant Antoni: 6. Cova del Pantà de Foix; 7. Cova de l’Avi.

\begin{tabular}{|c|c|c|c|c|c|c|c|c|}
\hline \multirow[b]{2}{*}{ Arrowheads } & \multirow[b]{2}{*}{ Butt type } & \multicolumn{7}{|c|}{ Sites } \\
\hline & & 1 & 2 & 3 & 4 & 5 & 6 & 7 \\
\hline \multirow{4}{*}{$\begin{array}{l}\text { Diamond-shaped point } \\
\text { complete }\end{array}$} & Flat butt & & & & & & & \\
\hline & Dihedral butt & & & & & & & \\
\hline & $\begin{array}{l}\text { Undetermined } \\
\text { butt }\end{array}$ & & & + & & & + & \\
\hline & Missing & + & ++++ & +++ & ++++ & & & +++ \\
\hline $\begin{array}{l}\text { Diamond-shaped proximal } \\
\text { fragment }\end{array}$ & Missing & & + & & & & & \\
\hline $\begin{array}{l}\text { Diamond-shaped mesial } \\
\text { fragment }\end{array}$ & & & & & & & & + \\
\hline \multirow{2}{*}{$\begin{array}{l}\text { Winged and stemmed point } \\
\text { complete }\end{array}$} & Punctiform butt & & & & + & & & \\
\hline & Missing & +++++ & + & & + & & & \\
\hline $\begin{array}{l}\text { Winged and stemmed point } \\
\text { proximal fragment }\end{array}$ & & & & & & & & + \\
\hline $\begin{array}{l}\text { Winged and stemmed point } \\
\text { distal fragment }\end{array}$ & & & & & + & & & \\
\hline Total & & 6 & 6 & 4 & 7 & 0 & 1 & 5 \\
\hline
\end{tabular}

\subsection{Use-wear analysis}

A first approach to the use-wear analysis has been carried out for two sites. Cova de la Guineu and Avenc de St. Antoni (Figure 9). The use-wear of another site, Cova del Pantà de Foix, was recently published (Cebrià et al. 2013).

Stereo and metallographic microscopes (Leica MZ16 of 20X-40X, and a Leica DM2500M of 50X-400X, both with Helicon Focus software) were combined. The results of the macroscopic and microscopic analyses were compared with the experimental lithic tool reference collection hosted at the Milà i Fontanals Institution (CSIC).

\section{Data results and Interpretation}

In this paper the focus is mainly on the macroscopic archaeopetrological data. The data obtained from the analyses carried out on the lithic burial goods can be seen in Table 4 .

The category of unidentified raw materials includes tabular chert, whose origin still remains unknown (2 large blades from Cova de la Guineu and one arrowhead from Cova de la Font del Molinot), as well as highly patinated blades or arrowheads, of which the general environmental deposition must to be defined more carefully, in the absence of clear evidence of macroscopic parameters.

The main lithic raw material represented in the burial context of the analysed region is chert of a continental-lacustrine depositional environment, characterised mainly by sections of stems and oogonia of charophyta algae and some sections of gastropods. The original sources for these types of chert must be located around 150 kilometres northwest from the region in the Ebro basin. It was used mainly in large blades (n: 38), but poorly used in arrowheads (n: 2). Regardless, the absolute number of large blades has to be taken with prudence considering that some of these blanks could be fragments of the same large blade. Finally, this is the raw material for the two daggers. 

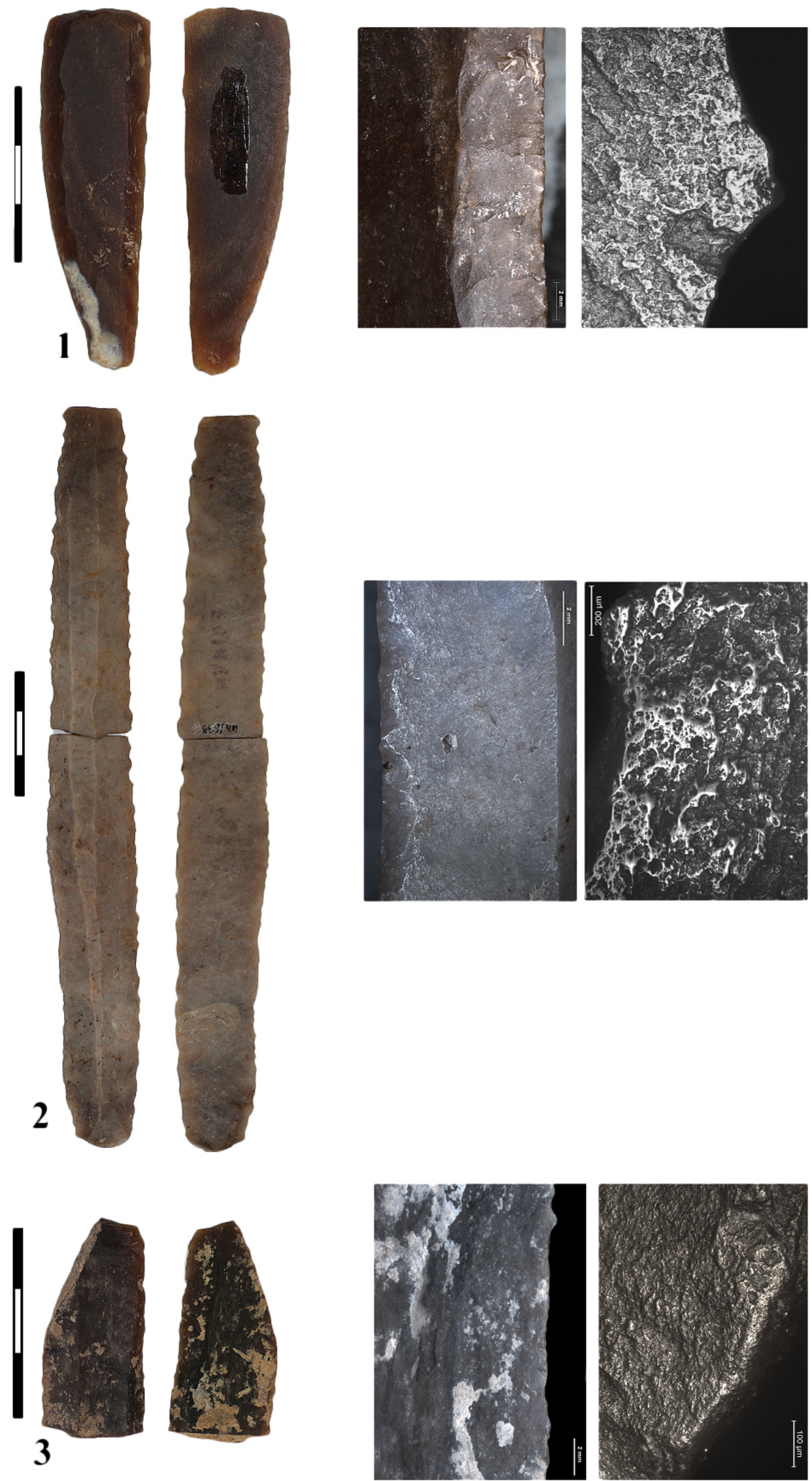

Figure 9. Three examples of analysed large blades (Photo J.F. Gibaja). Numbers 1 \& 2 had been used for harvest the cereals or in latter works, number 3 , have been used too in other works, as cutting meat and scraping hide or wood. Scale bars $=3 \mathrm{~cm}$ (in $1 \mathrm{~cm}$ segments). 
Table 4. Distribution of large blades, arrowheads and daggers according to raw materials. Abbreviations: Marine (M). Continental lacustrine (C-L). Continental brecciated (C-B). Continental evaporitic (C-E). Burned (B). Unidentified (U). Y axis: Blade or blade fragment (B). Arrowhead (A). Dagger (D). Unidentified (U)

\begin{tabular}{|c|c|c|c|c|c|c|}
\hline Site & $\mathbf{M}$ & C-L & C-B & C-E & B & $U$ \\
\hline \multirow{4}{*}{ C. de l'Avi } & B: & B: 2 & B: & B: 1 & B: & $\mathrm{B}: 1$ \\
\hline & A: & A: & A: & A: 5 & A: & A: \\
\hline & D: & D: 1 & D: & D: & D: & D: \\
\hline & $\mathrm{U:}$ & U: & U: & U: & U: & U: \\
\hline \multirow[t]{4}{*}{ C. de la Font del Molinot } & B: 6 & B: 6 & B: & B: & B: & B: 1 \\
\hline & A: & A: 1 & A: & A: 4 & A: & A: 1 \\
\hline & D: & $\mathrm{D}: 1$ & D: & D: & D: & D: \\
\hline & $\mathrm{U:}$ & U: & U: & U: & U: & U: \\
\hline \multirow[t]{4}{*}{ C. del Pantà de Foix } & B: 1 & B: 5 & B: & B: & B: & B: \\
\hline & A: & A: 1 & A: & A: & A: & A: \\
\hline & D: & D: & D: & D: & D: & D: \\
\hline & U: & U: & $\mathrm{U:}$ & U: & U: & $\mathrm{U:}$ \\
\hline \multirow[t]{4}{*}{ C. de la Guineu } & B: & B: 15 & B: 2 & B: 2 & B: 3 & B: 5 \\
\hline & A: & A: & A: & A: 3 & A: & A: 3 \\
\hline & D: & D: & D: & D: & D: & D: \\
\hline & U: & $\mathrm{U:}$ & U: & U: & U: & U: \\
\hline \multirow[t]{4}{*}{ C. Foradada } & B: & B: 2 & B: & B: & B: & B: \\
\hline & A: & A: & A: & A: 3 & A: 2 & A: 2 \\
\hline & D: & D: & D: & D: & D: & D: \\
\hline & U: & $\mathrm{U:}$ & U: & $\mathrm{U:}$ & U: & U: \\
\hline \multirow[t]{4}{*}{ Esquerda de les Roques del Pany } & B: & B: 6 & B: & B: 1 & B: & B: 5 \\
\hline & A: & A: & A: & A: 3 & A: & A: 1 \\
\hline & D: & D: & D: & D: & D: & D: \\
\hline & U: & $\mathrm{U:}$ & U: & U: & U: & U: \\
\hline \multirow[t]{4}{*}{ Avenc de St. Antoni } & B: & B: 2 & B: & B: & B: & B: 1 \\
\hline & A: & A: & A: & A: & A: & A: \\
\hline & D: & D: & D: & D: & D: & D: \\
\hline & U: & $\mathrm{U:}$ & U: & U: & U: & U: \\
\hline Total & 7 & 42 & 2 & 22 & 5 & 20 \\
\hline
\end{tabular}

Part of these goods, in fact, the two daggers and several large blades (n: 12: Cova de la Guineu (5); Esquerda de les Roques del Pany (3); Cova de la Font del Molinot (1); Avenc de St. Antoni (1); Cova del Pantà de Foix (1); Cova de l'Avi (1)) taking into account their macroscopic features, could be related with a specific type of continental-lacustrine chert: Apt-Forcalquier chert, which was widely distributed over more than 500 kilometres in the form of large blades during these phases of late Catalan prehistory. Some common technological features allowed for the recognition of the Apt-Forcalquier large blades such as basically their very regular edges, a low arched profile in the mesial part, narrow butts and bulb scars. The chert dagger blades with parallel, 'ripple-flake' retouch covering their entire surfaces, made from bifacial polished roughouts, have a geographical distribution ranging from western Provence to Valencia, passing through the Rhone Valley, Languedoc, Rousillon and Catalonia. These types of chert daggers, known as the Font del Molinot type, with a triangular tang, and the Chataigniers type (C. de l'Avi) (Figure 8), with a short and irregular tang, are canonical productions of Forcalquier's workshops (Plisson et al. 2006; Vaquer 1990; 2012; Vaquer \& Briois 2006; Vaquer et al. 2014). 
The second raw material in number is the continental evaporitic chert, in this case characterised by lenticular pseudomorphs of gypsum, hematite granules and megaquartz crystal mosaic fabrics in the pore filling. This type of chert was used for more than half of the arrowheads (n: 18) and is poorly represented among large blades or fragments (n: 4). This lithic raw material exhibits macroscopic features consistent with continental evaporitic depositional environments. Many geological Eocene and Oligocene formations located west or south of the analysed regions could deliver this type of raw material. In both cases, the nearest travelled distance would be defined as regional.

Marine chert artefacts are not well represented in the burial contexts of the Penedès. Only seven blades could be related with a marine origin depositional environment, characterised basically by foraminifera and other micropalaeontological fragments of bioclasts. It should be noted that a total of four of these blades in Cova de la Font del Molinot, catalogued as Middle Neolithic, are heat-treated blades of Bedulian chert. They were catalogued due to their presence at the site, but nevertheless they are not stratigraphically or cultural related to the Late Neolithic. Marine cherts were not knapped for the manufacture of projectile points.

Burnt artefacts specially affect only two sites - Cova de la Guineu (3 large blades) and Cova Foradada (2 arrowheads). It is still not clear whether the cremation that affects also some of the human remains is exclusively related to ritual practices, or whether it could also be related to post-depositional processes at the sites.

Finally, only 2 large blades at Cova de la Guineu have been linked to a brecciated texture chert that still remains of unknown origin.

The use-wear study for Cova de la Guineu and Avenc de St. Antoni demonstrates that the main part of the large blades analysed had been used for harvesting cereals or in latter works related with handling the stems on the floor, as deep abrasion traces have been demonstrated. The edges also show intensive reshaping. Finally, some of these pieces have also been used in other works, such as cutting meat and scraping hide or wood.

At Cova del Pantà de Foix, all of the large blades (n: 6) were used intensively to harvest cereals, with frequent reshaping of the edges also. The arrowhead from this site shows an impact fracture; probably introduced into the site inside a corpse (Cebrià et al. 2013).

The use-wear analysis reveals that all of these blades, even those of foreign origins, were not merely luxury item grave goods. Far from this idea, they had to have also been considered functional, or multifunctional, items. However, it is obvious that they were special materials and that they had been selected independently of what they were used for previously.

\section{Discussion}

The presence in the seven analysed sets of chert that characterize distinct geological formations (continental environments, marine, etc.) with a diverse geographical distribution over a wide exogenous territory as far as the Penedès, necessarily demonstrates the existence of mechanisms of circulation of certain lithic materials by exchange lines, in some cases, such as the Apt-Forcalquier chert, over long distances, and in other cases, over distances of minor supra-regional order (continental-lacustrine chert).

The mechanisms by which this exchange was carried out still remain unknown. Neither is it known whether the different laminar product were distributed through the same networks, or if, on the contrary, they correspond to different supply routes, a fact that could explain the diversity of origins of the recognised raw materials, as well as their different numerical representation within the assemblages, with only certain productions such as continentallacustrine large blades being the result of a larger or more well rooted exchange network between the communities of this period within the analysed territory, as their presence seems to suggest. 
The absence of evidence of the Chaîne Opératoire of Apt-Forcalquier chert in the Catalan lithic assemblages, lead to the supposition that the dispersion of the blades was done as trade items, and highly complex technological tools of this type of raw material were only distributed in a few cases (two daggers).

Thus, with regard to the large blades, considering the nature of the remains themselves, and their intense utilization, as well as their representation in the assemblages (they appear at all the analysed sites), it must be considered that the exchange of large blades had to have been carried out in a generalized and organized way. Its importance in the economic sphere of those societies is clear, as the use-wear analyses have shown; however, in turn, their symbolic importance is obvious and demonstrates itself in the sphere in which they were deposited in funerary contexts. This conclusion affects both the main siliceous materials (continentallacustrine chert) and the imported long-distance production (Apt-Forcalquier chert), consequently demonstrating a similar management for both materials. It should also be pointed out the differential preference for banded chert for large blades, which seems obvious, specially taking into account the amount of blades with this macroscopic aspect, in comparison to the number of arrowheads with the same characteristics. In 12 large blades, their macroscopic features links them to the Apt-Forcalquier chert (Provence, France), which was widely distributed in the form of large blades during these phases of late Catalan prehistory. The uncommonness and high technical skills required to knap these large blades and daggers in Apt-Forcalquier chert, make us believe that the ability to purchase these items would not be generalized to the entire population. These objects were functional pieces that should be owned by the buried. They were not easily available, and consequently we assess that they played a role in defining social status.

Except for Cova Foradada, all of the deposits show the presence of large blades or fragments made from Apt-Forcalquier chert. This "anomalous" circumstance is accompanied by the fact that it is precisely this site where the small number of fragments of large blades is accompanied by the largest number of projectile points, a circumstance that could be attributed to several hypotheses, among which its chronology could be considered, that dates the burial level to the end of the analysed period, indicating a possible change in the value attributed to this type of chert.

Concerning the projectile elements analysed in this paper, it is observed that the raw materials reflect a geographical area that could be considered of regional or supra-regional scale, but closer to the sites than for large blades. These projectile points have been knapped mainly from varieties of siliceous raw materials of continental-evaporitic type (not AptForcalquier chert). In this case, the mechanisms of exchange take a secondary role in the interpretation, generally considering that we are facing relatively close supplies and regional production, since the geological formations likely to provide these materials have a wide geographical distribution, in neighbouring territories. On the other hand, many of these projectiles show small fractures that have been linked to their usage. It cannot be ruled out that these elements were introduced into the funerary contexts in the corpses themselves.

In all of the analysed sites, except in Avenc de Sant Antoni, the presence of projectile points has been observed. This circumstance at this site could be related to the history of the investigations.

\section{Conclusions}

The macroscopic characterization of a total of 67 large blades and blanks, 29 arrowheads and 2 daggers for the region of the Penedès shows their great variety regarding the geological and geographical origin of the siliceous raw material, very often coming from outside the analysed region (southern France, Ebro basin, southern Catalonia). In some cases, for those 
lithic materials whose origins still remain undetermined, new research must be done, to define from a geochemical point of view a finer characterisation of these materials.

The use-wear analyses clearly demonstrate the economic use of these long blades, regardless of the type of chert, before their use as grave goods.

\section{References}

Bronk Ramsey, C. 2013, “OxCal 4.2.2 Manual”. Retrieved 01 September 2016. URL: https//c14.arch.ox.ac.uk

Cebrià, A., Fullola, J.M., López-Onaindía, D., Mangado, X., Nadal, J., Ollé, A., Oms, F.X., Pedro, M., Ruiz, J., Subirà, M.E., Torrente, A., Vergès, J.M. 2013, La Cova sepulcral del Pantà de Foix (Castellet i la Gornal). De jaciment arraconat a jaciment modelic. In: III monografies del Foix. Colecció Documents de Treball. Sèrie Territori Vol. 24.

Diputació de Barcelona, Barcelona: p. 184-194. (in Catalan) (“The sepulchral cave of Pantà de Foix (Castellet i la Gornal) from ignored to modelic archaeological site")

Daura, J., Sanz, M., Oms, F.X., Martínez, P., Rubio, A., Tejero, J.M., Mangado, X., Vaquer, J., López-Cachero, F.J., Asensio, A., Álvarez, R., Fullola, J.M., Petit, M.A. 2015, La Cova de l'Avi (Vallirana, Barcelona) y el inicio del Neolítico final en el Nordeste de la Península Ibérica. Inhumaciones colectivas y nuevas redes de intercambio, Trabajos de Prehistoria, 72(2): 327-341. (in Spanish) (“Cova de l’Avi (Vallirana, Barcelona) and the beginning of the Late Neolithic in north-eastern Iberia. Collective inhumations and new exchange nets”) doi:10.3989/tp.2015.12157

Gibaja, J.F., Palomo, A., Terradas, X., Clop, X. 2004, Útiles de siega en contextos funerarios del 3500-1500 cal ANE en el noreste de la Península Ibérica: El caso de las grandes láminas de sílex, Cypsela, 15: 187-195. (in Spanish) ("Harvest tools in burial contexts 3500-1500 cal BCE in north-eastern Iberia: The case of large blades”) URL: http://www.raco.cat/index.php/Cypsela/article/view/175772/

Gibaja, J.F., Terradas, X., Palomo, A., Clop, X. 2009, Las grandes láminas de sílex en contextos funerarios del Neolítico final-Bronce inicial en el nordeste peninsular. In: Europa al final de la Prehistòria. Les grans fulles de sílex (Juan Francisco Gibaja, Xavier Terradas, Antoni Palomo, Xavier Clop, Eds.), Monografies Vol. 13. Museu d'Arqueologia de Catalunya, Barcelona: p. 63-73. (in Spanish) ("The large blades in burial contexts from Late Neolithic to Early Bronze Age in northeastern Iberia”)

Juan-Cabanilles, J. 2008, El utillaje de piedra tallada en la Prehistoria reciente valenciana. Aspectos tipológicos, estilísticos y evolutivos. Serie de Trabajos Varios Vol. 109. Diputación de Valencia, Valencia, 300 p. (in Spanish) ("Knapped stone tools in the late prehistory of Valencia. Typological, stylistic and evolutionary aspects”)

Oms, F.X., Cebrià, A., Mestres, J., Morales, J.I., Pedro, M., Vergès, J.M. 2016. Campaniforme i metal-lúrgia en un espai sepulcral del III mil·lenni cal. BC: La Cova de la Guineu (Font Rubí, Alt Penedès). In: Jornades d'Arqueologia del Penedès (Esteve, X., Miró, C., Molist, N. \& Sabaté, G., Eds), Institut d’Estudis Penedesencs, Vilafranca del Penedès: p. 109-116. (in Catalan) ("Bell beaker and metallurgy in a burial context of the $3^{\text {rd }}$ millennium cal. BC: La Cova de la Guineu (Font Rubí, Alt Penedès))"

Plisson, H., Bressy, C., Briois, F., Renault, S. 2006, Les productions laminaires remarquables du midi de la France à la fin du Néolithique: les bases d'un programme collectif de recherche. In: Actes de la Table Ronde de l'EHESS. La fin de l'Âge de Pierre en Europe 
du Sud (Vaquer, J. \& Briois, F., Eds), Archives d’Écologie Préhistorique, Toulouse: p. 71-81. (in French) ("The remarkable laminar productions of the south of France at the end of the Neolithic period: The basis of a collective research program”)

Reimer, P. J., Bard, E., Bayliss, A., Beck, J. W., Blackwell, P. G., Bronk Ramsey, C., Buck, C. E., Cheng, H., Edwards, R. L., Friedrich, M., Grootes, P. M., Guilderson, T. P.; Haflidason, H.; Hajdas, I.; Hatté, C.; Heaton, T. J.; Hoffmann, D. L.; Hogg, A. G.; Hughen, K. A., Kaiser, K. F., Kromer, B., Manning, S. W., Niu, M., Reimer, R. W., Richards, D. A., Scott, E. M., Southon, J. R., Staff, R. A., Turney, C. S. M. y van der Plicht, J. 2013, IntCal13 and Marine13 radiocarbon age calibration curves 0-50,000 years cal BP. Radiocarbon 55 (4): 1869-1887. doi:10.2458/azu_js_rc.55.16947

Terradas, X., Palomo, A., Clop, X., Gibaja, J.F. 2005, Primeros resultados sobre el estudio de grandes láminas procedentes de contextos funerarios del noreste de la Península Ibérica. In: Actas del III Congreso del Neolítico en la Península Ibérica (Arias Cabal, P., Ontañon Peredo, R., García-Moncó Piñeiro, C., Eds.), Monografías del Instituto Internacional de Investigaciones Prehistóricas de Cantabria, Vol.1, Servicio de Publicaciones de la Universidad de Cantabria, Santander: p. 349-375. (in Spanish) ("First results regarding the study of large blades provided by burial contexts in northeastern Iberia”)

Terradas, X., Gibaja, J. F., Palomo, A. 2012, Producing for the dead, using while alive: lithic tools production and consumption in the Late Neolithic of North-Eastern Iberia. In: Social, Economic and Symbolic Perspectives at the Dawn of Metal Production (Conati Barbaro, C. \& Lemorini, C., Eds.), BAR International Series Vol. 2372, Archaeopress, Oxford: p. 41-51.

Vaquer, J. 1990, Le Néolithique en Languedoc Occidental. Éditions Centre National de la Recherche Scientifique (CNRS), Paris, 397 p. (in French) ("The Neolithic in western Languedoc”)

Vaquer, J. 2012, Réflexions sur échanges de biens matériels lithiques entre le Midi de la France et le nord de la Péninsule Ibérique au Néolithique et au Chalcolithique”. In: Actes del Congrés Internacional Xarxes al Neolític - Neolithic Network (Borrell, M., Borrell, F., Bosch, J., Clop, X. \& Molist, M., Eds.), Rubricatum Vol. 5, Museu de Gavà, Gavà: p. 565-574. (in French) ("Reflections on the exchange of lithic material goods between the south of France and the north of the Iberian Peninsula in the Neolithic and Chalcolithic")

Vaquer J. \& Briois F. (Eds.) 2006, La fin de l'Age de pierre en Europe du sud. Matériaux et productions lithiques taillées remarquables dans le Néolithique et le Chalcolithique du sud de l'Europe. Edition des Archives d'Ecologie Préhistorique. Toulouse, 284 p. (in French) ("The end of the Stone Age in southern Europe. Materials and remarkable lithic knapped productions during the Neolithic and the Chalcolithic in the south of Europe”)

Vaquer J., Martin Colliga A., Juan Cabanilles J., Bordreuil M., Galant Ph. 2014, Les poignards à retouches parallèles couvrantes sur préformes polies en silex de Forcalquier dans la zone nord-occidentale de la Méditerranée. In: Entre archéologie et écologie, une préhistoire de tous les milieux: Mélanges offerts à Pierre Pétrequin (Arbogast, R.-M. \& Greffier Richard, A., Eds.) Annales Littéraires de l'Université de Franche Comté. Série Environnement, Société et Archéologie, Vol. 18, Presses Universitaires de Franche Comté, Besançon: p. 129-155 (in French) ("Parallel-flaked daggers made from polished preforms in Forcalquier flint from the northwest Mediterranean region”) 